\title{
Media and Knowledge
}

\section{Some Pragmatist Remarks about Media Philosophy within and beyond the Limits of Epistemology}

\author{
Mike Sandbothe
}

The favorite philosopher of one of my favorite philosophers once summarized the metaphilosophical postulate which is the basis for one of his main works by highlighting: "(...) that the distinctive office, problems and subject matter of philosophy grow out of stresses and strains in the community of life in which a given form of philosophy arises, and that, accordingly, its specific problems vary with the changes in human life (...)" (Dewey 256). His controversial follower, Richard Rorty, said the following about Dewey's comments: "the stresses and strains Dewey has in mind are those that arise from attempts to pour bubbly and expansive new liquids into old bottles" (Rorty 5).

Somewhat more concretely formulated, the suggestion, which the two pragmatists present to their colleagues, consists of philosophical thinking not only, and not primarily as a theoretical reflection on the conditions of the possibility of understanding truth, freedom, and beauty. Instead, the authors I have quoted would like to make a contribution to rehabilitate a "practical" form of philosophical work in the Aristotelian sense; a type of goal-oriented activity that might complement the more technical branches of philosophical reflection which have been successfully administered in the professionalized areas of academic teaching and research, such as ethics, aesthetics, logic and theory of science.

For Aristotle, it was already clear that the criteria of a valuable and successful life are not to be theoretically founded in practical philosophy. Instead, by practical philosophers (in the eminent and authentic sense), these criteria have to be taken for granted: not as abstract axioms, but as historically given clusters of habits, values and beliefs. The specific cluster, which Aristotle described with a view of the erudite Athenian as a harmonious interplay of ethical and dianoetic virtues, functions in his practical philosophy not so much as a subject of theoretical knowledge, but primarily as a tool of moral orientation and as a guideline for political action. Here is a quote from the second book of the Nicomachean Ethics: "Since, then, the present inquiry does not aim at theoretical knowledge like the others for we are inquiring not in order to know what excellence is, but in order to become good (...)" (Aristotle 1743). And Aristotle adds: "otherwise our inquiry would have been of no use" (Aristotle 1743).

At current, a transition from the typographic and audio-visually shaped industrial community type of the past to the more synesthestically designed multi-media cultures of the future is taking place. This shift not only provokes the theoretical concepts and established paradigms of philosophical thinking, but, at the same time, has metaphilo- 
sophical implications. At least that is how the working hypothesis reads which I would like to present here.

My reflections are divided into three parts. In the first part I will first say something about the current conditions of the epistemological debate, which, in contemporary philosophy, is known under the heading "realism versus anti-realism". In the second part I will analyze the different assessments of an epistemologically inspired philosophy of media that are developing at the present. In the third and last part I finally will discuss how the relationship between media and knowledge could look from a metaphilosophical point of view that orients itself not alone to the axioms of a theoretical, but rather beyond that to the goal oriented guidelines of a practical understanding of philosophy (in the old Aristotelian sense).

\section{The Stalemate of Contemporary Theory of Knowledge}

The debate about realism vs. anti-realism, as Michael Dummett once called it (Dummett, 1978), finds itself at the centre of contemporary theories of knowledge. This applies not only to the area of analytic philosophy, but also to the intellectual world of continental philosophy. On the one hand, the controversy refers to questions about the ontological status with regard to objects of perception, numbers, values or mental states. On the other hand, it refers to the question about the status of true statements. The epistemological occupation with these kind of questions goes back to Descartes and Kant. Historically it emerged from the endeavors of modern philosophy to guarantee the reality of the real and the truth of our beliefs in a secular manner, i.e. without recourse to divine instances.

Both realist and anti-realist epistemologies try to forge weapons against radical doubt. Radical doubt is a position which is characteristic of the sceptic (Stroud, 1984). The sceptical position indicates that there is possibly much about which we do not know, and that most or even everything of what we know could be completely different than what we actually mean. In order to dispel the doubts of the sceptic, realists and antirealists respectively come up with different examination procedures that are supposed to help reliably identify and effectively differentiate true, wrong and meaningless beliefs. Therefore, the specificities of the different examination procedures results from the specificities of the different domains, which, by means of these examination procedures are set to each other into relationships.

Realistic examination procedures refer to the relationship which is supposed to exist between an individual belief or a set of beliefs and the range of the so-called non-beliefs. The realistic positions differ internally with regards to the question whether and how the world of the so-called non-beliefs is to be determined and described in detail. Antirealistic examination procedures circumvent this problem by not trying to explain the truth of a belief by the reference to something that is supposed to be a non-belief, but by the appeal on the conceptual schemes which determine our beliefs as their formal conditions of possibility. The anti-realistic positions differ with regards to the question whether and how categories, schemes, and conceptual rules of generating knowledge differ from simple beliefs and complex belief networks, and, furthermore, with regards to the question whether and how an independent area of epistemological research can be defined.

The interesting specificity of the current position of the debate around realism and anti-realism consists of the fact that within philosophy an awareness of the stalemate 
which exists between realistic and anti-realistic positions has been increasing. The stalemate itself results from the circumstance that the criteria, to which realistic and antirealistic examination procedures refer, are equally under-determined. While the realists argue about whether, and how, an external domain outside the world of our beliefs can be proven as neutral criteria for their examination, the anti-realists are trying to solve the recourse problem already described by the late Wittgenstein. This problem consists of the fact that the application of constitutive schemes to single cases of concrete beliefs presupposes high-level schemes that rule the application procedure itself. But for them the same application problem obviously arises again and must be solved by using metarules. Thus, the cycle repeats itself ad infinitum.

A number of authors have concluded from this deadlock, that they must look at the initial epistemological question again more carefully. As a result, two basic strategies can be distinguished. The first one consists of surrendering to the sceptic and, even more, to actively identify with him. This is exactly what philosophers such as Odo Marquard in Germany and Peter Heintel in Austria have done, albeit with different objectives. The other basic strategy in contrast, is to neither fight nor share the sceptics' doubt, but rather not to take it seriously. Contextualists, interpretationalists, and pragmatists realize this second strategy differently.

In contrast to contextualists such as Michael Williams (Williams, 1996), interpretationalists such as Donald Davidson do not simply put the epistemological topic ad acta. Instead Davidson (following Quine) pleads for the development of a naturalist renewal and externalist reformulation of the epistemological discourse (Davidson, 2001, 2005). His central argument, upon which the interpretationalist refutation of the sceptic is based, is that most of our beliefs are true simply because they are what they are: beliefs. According to Davidson this is the case because of the manner in which human beings at very rudimentary levels in a triangulated situation of interpretation learn to have the beliefs that they actually have.

The triangulated language acquisition situation described by Davidson is constituted by a child (1), an adult who is teaching the child (2), and a shared environment (3). The child is conditioned in the process of language acquisition to learn to see and describe that what the adult sees and shows in the way the adult does. In this respect, the child does not learn some abstract language schemes, but instead is introduced by means of causal sanctioning in a number of language-interpreted perception situations (Davidson, 2001).

From an interpretationalist perspective, the network of beliefs we learn to have by means of triangulated language acquisition, is not at all based on an abstract representationalist relationship between language and reality. The very idea of such a relationship opens the door for the sceptic. Instead, according to Davidson, our interactive use of language is based on a socially anchored network of causal connections which exist between the content and the inner-worldly causes of our simple and most rudimentary beliefs.

Inspired by Davidson, but at the same time moving one step further, pragmatists such as Richard Rorty suggest a social-historical reconstruction of the current discourse situation in epistemological affairs (Rorty, 2007). More specifically, Rorty points out that the classical problems of modern theory of knowledge, in the history of secularization, had an important function as a cultural-political tool of democratic emancipation. But in the successfully secularized societies of the 21 . century, this function becomes increasingly less important. For this reason Rorty suggested a pragmatist reformulation of Davidson's approach without using the epistemological vocabulary (Rorty, 1998). 


\section{Three Types of Epistemologically Oriented Media Philosophy}

The new international research field of media philosophy functions as a catalyst within the different sub-disciplines of academic philosophy, as well as with a view of the closely related disciplines of media, communications, and information sciences, which, at the present time are converging. If one can comprehend how the media turn of the epistemological debate in the second half of the 90's developed, the intradisciplinary relevance of a media-philosophical specialized division becomes clear. In this regard, Sybille Krämer and Martin Seel take the position that the epistemological stalemate can be decided in favor of one of the two sides by appealing to a philosophically spelled-out concept of media and/or mediality.

In their introduction to the volume Schrift, Medien, Kognition, Sybille Krämer and Peter Koch emphasize that they (with Niklas Luhmann) are convinced that "everything that is known, thought, or said about the world, (...) depends on what can be known, thought and said in media," (Koch and Krämer 12). From this, they conclude that our belief-constitutive schemes of knowledge are not beliefs in themselves, but rather function as material artefacts that program the human mind, and therefore undermine or even dissolve the recourse problem as described by Wittgenstein (see above). The problem with this pretended (dis-)solution, however, is that we use media in a number of different ways, and that it is not the so-called (and quite abstract) mediality of the media as such, but the real use of concrete media as tools of perception, communication, and transmission which affects our 'epistemic' practices (Taylor/Saarinen 1994, Sandbothe 2005).

At about the same time as Krämer/Koch made their point, Martin Seel tried to expand " our use of 'mediality' as much as meaningfully possible to show that it is compatible with a moderate, philosophical realism,"' (Seel 249). His strategy consists of "accomodating radical and operative constructionists, deconstructionists, interpretationalists and other emphatic anti-realists (...) as much as possible - in order to then bind them into a realistic rope"3 (Seel 249f, Note 7). Seel's counter mantra to the quoted Krämer-Slogan, reads as follows: "The thesis is not, that everything that is, is communicated in, by, and through media. Mediated by media is rather everything to which we have a perceiving relationship (...), ${ }^{4}$ (Seel 250).

Like Krämer, Seel also is deeply influenced by Luhmann. According to Luhmann, media are defined as differences which make differences, i.e. Luhmann understands media as loosely related elements, that can become connected to closely coupled forms. Such a form can, for its part, function again as media for the generation of higher-level forms. Likewise, a media, for its part, can be interpreted as the form of an underlying basic media. A popular example is the relationship of sounds, words, sentences and texts. On the one hand, words function as media in which sentences are created as forms, which then, for their part, serve as media for generating text forms. On the other hand, the words themselves can be understood as forms, which are produced in the media of sounds, that for its part, as a form, refers back to still simpler media, such as the media of noises.

The realistic payoff of Seel's version of Luhmann's media definition consists of the fact that Seel traces the game of media differences back to the area of our sensual perception media and, at the same time accentuates that all our perception and all our knowledge transcends the involved media from within. With respect to John McDowell, Seel assumes that language (as the very fundamental media of all human knowledge) is so structured, that without it we cannot refer to anything intentionally, but within it, at 
the same time, everything to which we refer to is necessarily understood as a languageindependent non-belief (McDowell 1994).

Seel's media philosophical achievement exists, on the one hand, in the transmission of these McDowellian thoughts about the intentional structure of language in the area of our media of perception and knowledge. On the other hand it exists in the defense of epistemological realism against the thesis that the digitalization of our media technologies could bring our realistic basic institutions in question. Seel's main defense strategy becomes explicit in the following quotation: "The media revolution does not make an epistemological revolution necessary. On the contrary - we understand it as a media revolution, historically speaking, only if we, in epistemological affairs leave the church in the global village"5 (Seel 261).

The philosophical argument that leads Seel to this strategy is based on the idea that the "integrated computer," which Seel calls the Internet and digital media as a whole, "is, in the first place, also a media of images"6 (Seel 263). Being media of knowledge, the media of images, according to Seel, are structured similarly to the language media. That means that its inner structure presupposes the reference to a media external reality. In other words, we understand a picture as a picture only if we interpret it as a sign of something that is not a sign itself: a so-called 'non-sign'. In this dialectic argumentation, we can, once again, easily recognize the McDowellian idea. This idea is the basis for Seel's moderate realism which he applies to different levels regarding the discussion of media philosophy. What Seel fails to adequately take into consideration is Brandom's and Davidson's quite convincing criticism of McDowell's position.

Robert Brandom's objection is that the intrinsic language reference to something language-independent is not necessary to be interpreted as a determining characteristic of language itself (Brandom, 1994, 2008). From Brandom's perspective, we should understand the objectivity of the reference much more as an inter-subjective commitment upon which we have implicitly agreed in the context of our concrete language use in historically and culturally determined social practices. From this, the following can be said: if social practices change, our socially organized commitment can also change and be replaced by a different one.

Davidson made a very concrete suggestion for such a change. In his opinion, we should try to safeguard the inter-subjective commitment of our linguistic references in the future neither through referring to an immanent language scheme, nor through referring to a supposedly language-independent content. Furthermore, he argues, that we should separate the latter issue totally from the merely scholastic question whether language itself or specific social practices constituted the very idea of referring to a language-independent content (Davidson, 2001, 2005).

In his book Medien der Vernunft. Eine Theorie des Geistes und der Rationalität auf Grundlage einer Theorie der Medien, Matthias Vogel tries systematically to unfurl the media- philosophical consequences which result from Davidson's suggestion. Vogel's ideas move beyond the Luhmann-inspired debate led by Seel and Krämer on media realism versus media constructionism. At the beginning of his book, the author states that the media-form-difference, which both, Seel and Krämer, have adopted (albeit very differently) from Luhmann, is nothing else than another brand of the epistemological dualism of scheme and content.

If one understands the production of meaning according to Davidson as the "internalization of an in the first instance external social process of interpretation," (Vogel, „Medien als Voraussetzungen für Gedanken” 118), i.e. as a self-ascription of a process 
that follows the model of understanding others, the design of the theoretical starting point changes. This is the case because the functional description of a postulated complex system of loose or coupled sign elements (Luhmann) will then be replaced by empirical research about simple interaction situations that are the main elements of the triangulated process of language acquisition (Davidson).

If one proceeds from Davidson's idea of the triangulated situation of language acquisition which briefly has been outlined in the first point, then according to Vogel, the acquisition of language-based communications practices necessitates the intuitive faculty to make use of non-linguistic communications practices. In order for a child to ascribe to itself the beliefs which the adult articulates regarding the shared environment and therefore to learn to perceive the environment like adults the child must already have the ability to refer to its own reactions and to identify the external cause of the adults' reactions as the very content of its own. According to Vogel this pre-linguistic type of self-reference develops on the basis of "mime, gestures, prosody, onomatopoeia, and other expressive tools“8 (Vogel „Medien als Voraussetzungen für Gedanken“ 124). These non-linguistic media are used by the parental attachment figure when interacting with the child. From such interactions, the child can then, in turn, use these media in order to structure its own experiences by triangulating them with the experiences of the adult and the shared environment.

Against the interpretationalist background of such considerations, in the course of his book, Vogel emphasizes the independent relevance of non-linguistic media, such as image, dance and music. So, by example of aesthetic thinking which is enabled by the arts, he shows us that non-linguistic media are, to a certain extent, to be understood in analogy to language-based media as social instruments that serve the "individualization or communication of thoughts, "9 (Vogel „Medien als Voraussetzungen für Gedanken 133). On the one hand Vogel consciously expands the concept of the mind around the dimensions of the non-linguistic and the artistic, but on the other hand he restricts its use to the area of perception and communications media. This exclusion of the technical media of transmission marks a fundamental difference which exists between interpretationalist and pragmatist media philosophers.

From the perspective of media-philosophical pragmatists like myself, our perception and communications media are to be set in relationship to the cultural terms of use which are created by the different media technologies of transmission, processing and storage of data. Time and space, the interplay of our sensory organs, images, language, dance, theatre, and music, as well as writing and numbers are what they are; but they are never independent from the technical media of transmission which delimit the spectrum of their use (Taylor/Saarinen 1994; Sandbothe 2005).

\section{Four Features of Media Philosophical Pragmatism}

In the second of his famous Lowell lectures from 1906, William James described the relationship of pragmatism to philosophical theories being in an academic competition with each other, as follows: "Pragmatism unstiffens all our theories, limbers them up and sets each one at work. (...). It has no dogmas, and no doctrines (...) it lies in the midst of our theories, like a corridor in a hotel. (...) all must pass through it if they want a practicable way of getting into and out of their respective rooms," (James 28-29).

Naturally James' corridor metaphor does not rule out that some theorists may prefer to climb out of a window or may simply want to stay in their hotel rooms and have 
everything they need to survive brought to them at their desks. It only means, that the easiest path from theoretical to practical philosophy (understood in the Aristotelian sense) goes through the corridor of pragmatism. In this completely liberal and relaxed sense, I would like to finally outline the relationships between epistemology, media theory, and media practice. To this end, I will try to characterize the basic attitude of the media philosophical pragmatist through four main traits.

The first of these traits lies therein, that the media philosophical pragmatist understands herself as an initiator and moderator of the conversation, that the epistemologically oriented media philosophers conduct with each other. The second trait comes in her tendency to make the intra-disciplinary led discourse between media philosophers useful for inter- and cross-disciplinary discussions as well. This aspect of her activity is especially useful in the current situation in which the humanities reorganize themselves by stepwise integrating and partially even focusing on media- and cultural-scientific dimensions of their work.

Furthermore it can be said that we, at present, not only in the media and cultural studies, but also in the social, technical and natural sciences experience an anti-realistic, i.e. constructionist counter-movement to the long-lasting dominance of realism as a leading paradigm. In face of this situation, the task of a pragmatist research ecology inspired by James is to resist, with well-founded alternatives, the newly-announced anti-realistic orientation which reaches from the linguistic or iconic over cultural and performative turns to the so-called "media turn" of our times.

The third trait of the media philosophical pragmatist is expressed by the fact that she takes a balancing and counter-measuring position also regarding the widespread preferencing of specific individual media or media types as superior to other individual media or media types. At the centre of a pragmatist concept of media philosophy is the systematic attempt to analyze and balance the media-ecological interplay between perception media such as space, time, and sensory organs, communications media such as body, image, language, writing, music, dance, and theatre, and (last but not least) technical transmission media such as voice, press, film, television and the internet.

In order to bring the fourth and last trait of the media philosophical pragmatist into perspective, allow me to quote James once more: "The finally victorious way of looking at things will be the most completely impressive way to the normal run of minds," (James $20)$. If one relates this remark to the current debate, then a practical orientation of media philosophical thinking comes into view that transcends the dimension of inner academic cross-linking, by opening up a pretty long-term space of possible consequences. Media philosophical pragmatists tend to evaluate theories not only and not primarily by considering how they stand the test in the inner theoretical discourse. Instead, media philosophical pragmatists furthermore ask the question, what chance which theory might have to become, in its most popular form, an intuitive element of the common vocabulary with whose help the members of a transforming society (like ours) can describe themselves and communicate with each other in an effective and democratic way (Allen/Groeschner/Sandbothe 2009).

The speed with which our vocabulary has changed with regard to the spread of digital media has increased greatly. The institutionalization of the printing press in the $18^{\text {th }}$ century, and the establishment of the electronic media in the $19^{\text {th }}$ and $20^{\text {th }}$ centuries in this respect, led to an acceleration tendency which in the $21^{\text {st }}$ century has not only become stronger, but also globalized. If one takes the main ideas of Aristotelian ethics seriously, then the genuine task of a practical philosophy of media exists today in the 
development of concrete answers to the question, how can we establish new forms of media-based collective intelligence that improve a globalized form of democratic interaction between peoples and nations. This new, trans-national form of collective intelligence will be needed to cope with the global problems of planet earth that we are facing and that will probably not be solvable by focusing on a merely economic understanding of global politics.

Translation: Kenton E. Barnes

\section{Notes}

1. “alles, was über die Welt gewusst, gedacht, gesagt wird, (...) in Abhängigkeit von Medien wißbar, denkbar, sagbar (wird)“

2. “die Rede von 'Medialität' so weit wie irgend sinnvoll möglich auszudehnen, um dann zu zeigen, dass sie mit einem moderaten philosophischen Realismus kompatibel ist (...)“

3. "radikalen und operativen Konstruktivisten, Dekonstruktivisten, Interpretationisten und anderen emphatischen Anti-Realisten (...) so weit wie möglich entegegenzukommen - um ihnen dann einen realistischen Strick zu drehen $(\ldots)^{\text {“ }}$

4. "Die These lautet nicht, daß alles, was ist, medial vermittelt ist. Medial vermittelt ist vielmehr alles, wozu wir ein vernehmendes oder vornehmendes Verhältnis haben (...)“

5. "Die mediale Revolution macht keine erkenntnistheoretische Revolution nötig. Im Gegenteil: Wir können sie als die mediale Revolution, die sie historisch gesehen ist, nur begreifen, wenn wir in erkenntnistheoretischen Angelegenheiten auch im Global Village die Kirche im Dorf lassen."

6. (...) the "integrierter Computer," which Seel calls the Internet and the area of digital media, "wesentlich auch ein Bildmedium ist."

7. “(...) Internalisierung zunächst externer sozialer Interpretationsprozesse.”

8. “(...) mimischer, gestischer, prosodischer, lautmalerischer und anderer expressiver Mittel.”

9. “(...) Individuierung oder Kommunikation von Gedanken.”

\section{Works Cited}

Allen, Barry; Groeschner, Alexander, \& Sandbothe, Mike (forthcoming, 2009) Pragmatism as Cultural Politics. Cambridge: Cambridge University Press.

Aristotle (1743) Nicomachean Ethics, Book 2. 350 B.C. The Complete Works of Aristotle. The Revised Oxford Translation: Vol 2: $4^{\text {th }}$ Printing. Bollinger Series LXXI. Ed. Jonathan Barnes. Oxford: Princeton University Press.

Brandom, Robert (1994) Making it Explicit. Reasoning, Representing, and Discursive Commitment. Cambridge: Harvard University Press.

Brandom, Robert (2008) Between Saying \& Doing. Towards An Analytic Pragmatism. Oxford: Oxford University Press.

Davidson, Donald (2001) Subjective, Intersubjective, Objective. Oxford: Clarendon Press.

Davidson, Donald (2005) Truth, Language, and History. Oxford: Clarendon Press.

Dewey, John (1982) The Middle Works of John Dewey, Volume 12, 1899-1924: 1920, Reconstruction in Philosophy and Essays (Collected Works of John Dewey). Ed. Jo Ann Boydston. Carbondale: Southern Illinois University.

Dummett, Michael (1978) Realism, in: Michael Dummett. Truth and Other Enigmas. Cambridge: Harvard University Press.

James, William (1981) Pragmatism. Ed. Bruce Kuklick. Indianapolis: Hackett Publishing Company.

Koch, Peter \& Krämer, Sybille (1997) Schrift, Medien, Kognition. Über die Exteriorität des Geistes. [Writing, Media, Cognition: On the Exteriority of the Spirit.] Tübingen: Stauffenberg.

McDowell, John (1994) Mind and World. Cambridge, Mass.: Harvard University Press.

Rorty, Richard (1998) Truth and Progress: Philosophical Papers. Vol. 3. Cambridge: Cambridge University Press.

Rorty, Richard (2007) Philosophy as Cultural Politics: Philosophical Papers. Vol. 4. Cambridge: Cambridge University Press.

Sandbothe, Mike (2005) Pragmatic Media Philosophy, Online publication: sandbothe.net (German original: Pragmatische Medienphilosophie. Weilerswist: Velbrück 2001). 
Seel, Martin (1998) Medien der Realität und Realität der Medien. [Media of Reality and Reality of Media.], in Medien-Computer-Realität. Ed. Sybille Krämer. Frankfurt a.M.: Suhrkamp.

Stroud, Barry (1984) The Significance of Philosophical Skepticism. Oxford: Oxford University Press.

Taylor, Mark \& Saarinen, Esa (1994) Imagologies. Media Philosophy. London and New York: Routledge.

Vogel, Matthias (2001) Medien der Vernunft. Eine Theorie des Geistes und der Rationalität aufGrundlage einer Theorie der Medien. [Media of Reason, A Theory of the Spirit and the Rationality on the Foundation of a Theory of Media.] Frankfurt a.M.: Suhrkamp.

Vogel, Matthias (2003) Medien als Voraussetzungen für Gedanken in: Medienphilosophie. Beiträgezur Klärung eines Begriffs. [Media as a Prerequisite for Thoughts: in Media Philosophy. Contribution on an Explanation of a Term.] Frankfurt a.M.: Fischer.

Williams, Michael (1996) Unnatural Doubts. Epistemological Realism and the Basis of Scepticism. Princeton: Princeton University Press. 